

CASE CONFERENCE

Alan Jay Schwartz, MD

Frederick $A$. Hensley, Jr, MD

Section Editors

\title{
CASE 5-1996 \\ Thrombosis After the Use of a Heparin-Coated Cardiopulmonary Bypass Circuit in a Patient With Heparin-Induced Thrombocytopenia
}

\author{
Michel J. Van Dyck, MD, Edith Lavenne-Pardonge, MD, \\ Marie-Agnès Azerad, MD, Amine G. Matta, MD, \\ Maurice Moriau, MD, and Mark E. Comunale, MD
}

\section{Case Presentation}

A 64-year-old, $165-\mathrm{cm}, 58-\mathrm{kg}$ woman was admitted to the hospital with an inferior myocardial infarction. She underwent an emergent percutaneous transluminal coronary angioplasty (PTCA) complicated by an early reocclusion necessitating a second PTCA. The second PTCA complicated itself by the dissection of the right coronary artery (RCA), necessitating the placement of four stents in the RCA. The patient was then treated with porcine heparin (H) for 7 days. Warfarin was progressively titrated to a prothrombin time of $23 \%$ (international normalized ratio $=3.8$ ), and heparin was then stopped. After 3 days of effective warfarin treatment, she suddenly developed cardiogenic shock with third-degree atrioventricular block, necessitating resuscitation maneuvers, intubation, placement of an intra-aortic balloon pump, and a pacemaker. After this resuscitation, she recovered well except for a right hemiparesis that was attributed to a prolonged hypotensive state. Coronary angiography disclosed a reocclusion of the RCA. Fibrinolytic therapy was then administered, and a continuous infusion of heparin was reintroduced. Forty-eight hours after her ischemic event, a cerebral computed tomography (CT) scan was normal, and she had no neurologic sequelae. Nine days later, despite receiving a continuous infusion of heparin, she became ischemic in the right coronary artery territory, and an emergent coronary revascularization was planned.

While evaluating the patient's files, the attending anesthesiologist found that the platelet level was below $35,000 / \mathrm{mm}^{3}$ from the beginning of the second heparin administration 10 days earlier (Fig 1), and he suspected a syndrome of heparin-induced thrombocytopenia (HIT). Because of the presence of four stents in the patient's RCA and owing to her history of the repetitive coronary occlusions, the cardiologists refused to stop the heparin infusion. This infusion was therefore stopped in the operating room. A central venous catheter was already in place, a radial arterial catheter was then placed under local anesthesia, and both were flushed with $0.9 \%$ saline without heparin. Anesthesia was induced with etomidate and sufentanil, and muscle paralysis achieved with pancuronium. Anesthesia was maintained with midazolam, and a continuous infusion of sufentanil, $2 \mu \mathrm{g} / \mathrm{kg} / \mathrm{hr}$.

Iloprost is not available in Belgium; neither are the heparin substitutes proposed in the literature. The anesthesiologist had no experience with the use of low-molecularweight heparin (LMWH) during bypass. Therefore, he elected to use a heparin-coated cardiopulmonary bypass (CPB) circuit (HC-CPB) (Duraflo II; Bentley [Englewood, $\mathrm{CO}$, because of its theoretical advantages of biocompatibility and protection of platelets against activation caused by contact with the artificial surfaces. Only $50 \mathrm{IU} / \mathrm{kg}$ of porcine heparin were administered in place of the usual 300 $\mathrm{IU} / \mathrm{kg}$. Two saphenous grafts were sutured on the RCA. The procedure was performed under normothermia and intermittent antegrade warm blood cardioplegia. Aortic crossclamp time was 34 minutes, and CPB lasted 55 minutes. No pharmacologic support was needed to come off bypass.

The platelet level was $34,000 / \mathrm{mm}^{3}$ before surgery and $39,000 / \mathrm{mm}^{3}$ after $50 \mathrm{IU} / \mathrm{kg}$ of $\mathrm{H}$. It decreased to $22,000 /$ $\mathrm{mm}^{3}$ after 7 minutes of CPB, possibly because of hemodilution, and returned to $39,000 / \mathrm{mm}^{3}$ after discontinuation of CPB. Activated coagulation times with kaolin (ACT) (Hemotec; Medtronic [Uden, The Netherlands]) were 151 seconds before heparin administration, 231 seconds after $50 \mathrm{IU} / \mathrm{kg}$ of $\mathrm{H}, 445$ and 443 seconds during CPB, and 295 seconds after CPB. Only $10 \mathrm{mg}(2,000 \mathrm{IU})$ of protamine were then administered, and ACT returned to 148 seconds (Fig 2).

After administration of another 1,000 IU of protamine, the ACT was 82 seconds. Despite this, the patient was still bleeding actively. It was then judged that no more heparin was circulating at that time, and it was decided that it would

From the Departments of Anesthesiology and Hematology, Hemostasis and Thrombosis Unit, University Hospital St-Luc, Catholic University of Louvain Medical School (UCL), Brussels, Belgium, and the Division of Cardiac Anesthesia, Department of Anesthesta and Critcal Care, Beth Israel Hospital, Harvard Medical School, Boston, $M A$

Presented at the ZAK Twenty-fourth Central European Congress of Anesthesiology, Vienna, Austria, September 1995

Address reprint requests to Michel Van Dyck, MD, Department of Anesthesiology, Universtty Hospital St-Luc, avenue Hippocrate, 101821, B-1200 Brussels, Belgium.

Copynght $\odot 1996$ by W.B Saunders Company

1053-0770/96/1006-0020\$3 00/0

Key words: cardlac surgery, cardiopulmonary bypass, heparn, thrombocytopenia 


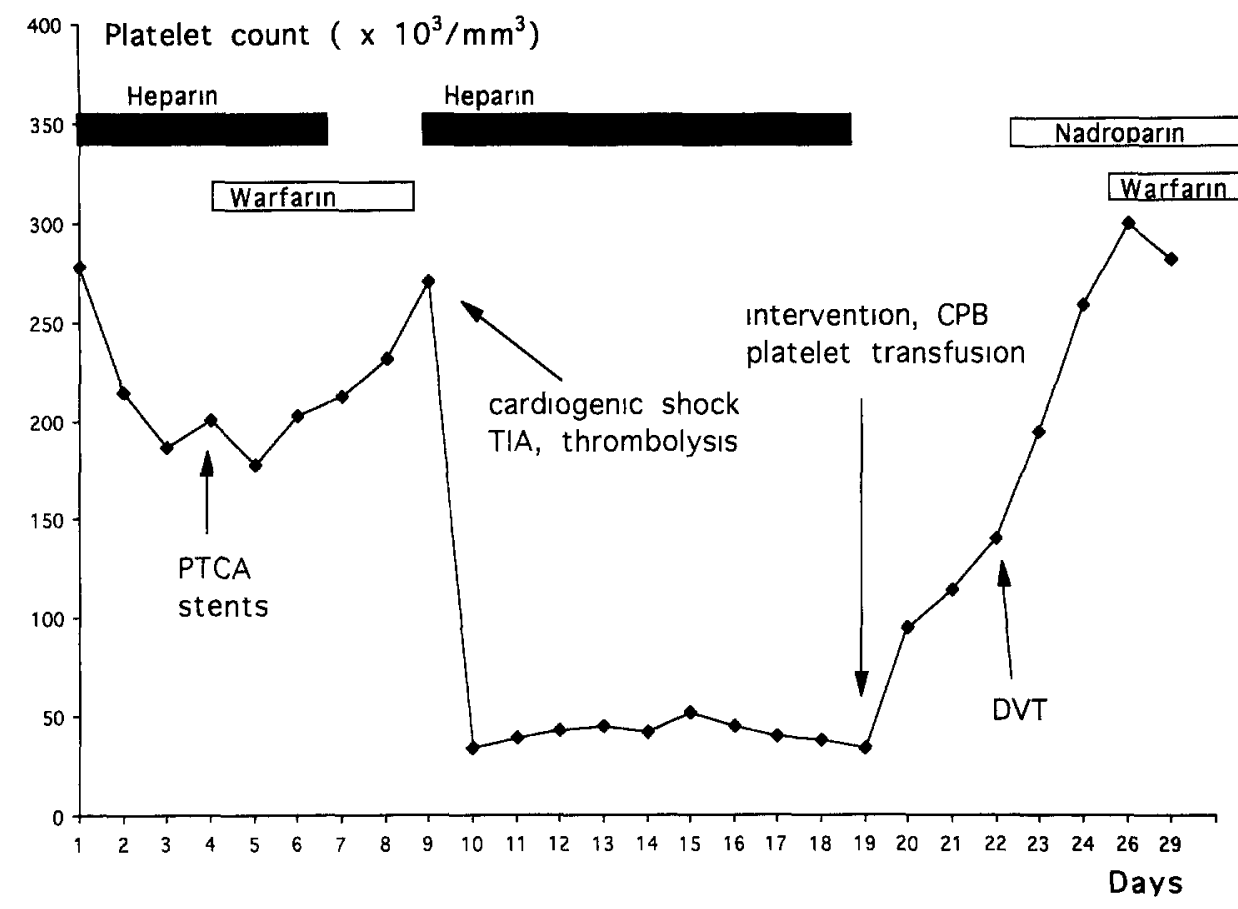

Fig 1. Course of the platelet count versus hospital stay. PTCA, percutaneous transluminal coronary angioplasty; TIA, transient cerebral ischemic attack, CPB, cardiopulmonary bypass; DVT, deep venous thrombosis. be safe to administer 6 units of platelet concentrate. All the blood lost during the procedure was processed (Cobe-IBM 2991, Lakewood, CO) and readministered to the patient: It constituted a volume of $650 \mathrm{~mL}$ of erythrocytes concentrate.

The patient was admitted to the intensive care unit (ICU) and there, because of continuous bleeding, received 6 more units of platelet concentrate. This administration stopped the bleeding, and the platelet count at that time was $83,000 / \mathrm{mm}^{3}$. Judged empirically as being safe, nadoparin and aspirin therapy were begun on the second postoperative day. The patient left the ICU on the second postoperative day, and from that moment her platelet count contınuously improved up to normal values (Fig 1). Unfortunately, on the third postoperative day, the patient developed swelling of both inferior limbs. A pelvic CT scan disclosed an extensive thrombosis of her two llac veins and the inferior vena cava up to the renal veins. Despite addition of warfarin to the therapy, only a partial resolution was obtained 25 days later.

She left the hospital on the 30th postoperative day, 49 days after her admission, under effective warfarin anticoagulation and without neurologic deficit.

\section{DISCUSSION}

HIT is a syndrome in which thrombocytopenia, sometımes accompanicd by thrombosis, develops after 5 or more days of heparm therapy. Although type $I$ is a direct aggregating effect of heparin on platelets, type-II HIT is an immunologic reaction, involving immunoglobulin $\mathrm{G}$ (IgG). These antibodıes bind to the antigenic complex formed by heparin and platelet factor-4 (H/PF4), and, in turn, activate the platelets through their $\mathrm{Fc}$ receptors. ${ }^{1-4}$ This syndrome is a challenge for the cardiac anesthesiologist because it can be precipitated by the heparin used during CPB. ${ }^{5-7}$ It can also occur after surgery, ${ }^{8,9}$ and in $20 \%$ of the cases is associated with arterial or venous thrombosis leading to severe morbidity. Several strategies to prevent or minimize its occurrence have been proposed including the following: blockade of platelet activation by aspirın, dipyridamole, or iloprost before heparin admunıstration ${ }^{7,10-12}$;

Fig 2 Evolution of the intraoperative $\mathrm{ACT}$ and platelet count 1. before CPB; 2, after heparin, $3,000 \mathrm{IU}, 3,10$ minutes $\mathrm{CPB}, 4,35$ minutes $\mathrm{CPB}, 5$, after $\mathrm{CPB}$, 6, after protamine, 2,000 IU; 7, after protamine, $1,000 \mathrm{IU} ; 8$, after 12 units of platelets

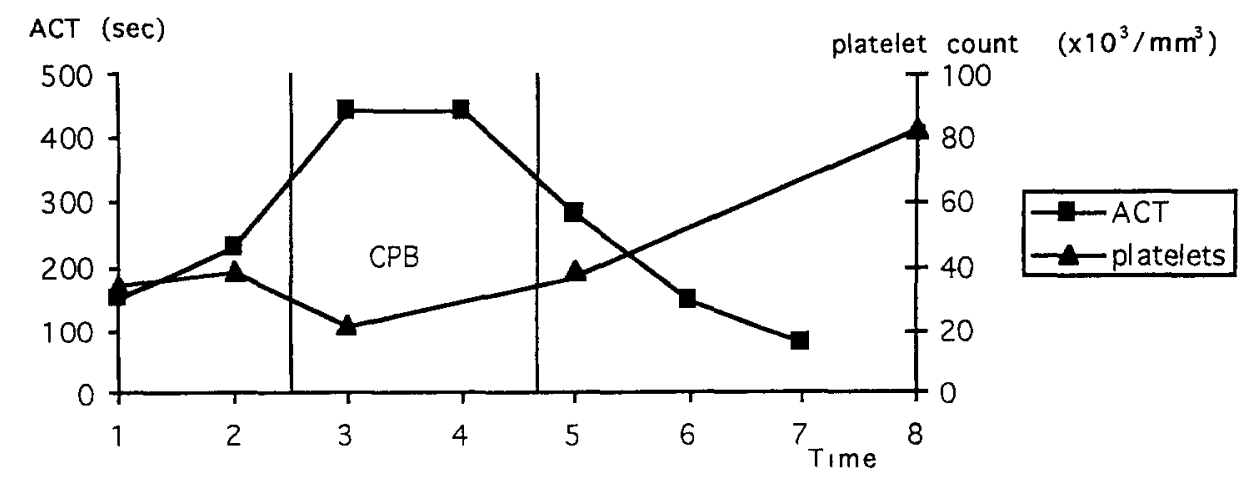


plasmapheresis before surgery ${ }^{13}$; substitution of ancrod, ${ }^{14,15}$ hirudin, ${ }^{16}$ or heparinoids ${ }^{17}$ for heparin; or use of LMWH. ${ }^{18.19}$

$\mathrm{HC}-\mathrm{CPB}$ prevents blood from clotting when it contacts the artificial surfaces and can reduce the degree of parenteral anticoagulation required for CPB, reduce complement activation, and simultaneously protect platelets from deterioration. ${ }^{20-22}$

Recent progress has been made in the understanding and management of the HIT syndrome. ${ }^{1-4}$ This entity has been divided into two types: Type I, the most frequent, is mild, of early onset, and reversible despite contınuation of heparin. It is not associated with thrombosis and appears related to a direct pro-aggregant effect of heparin binding on platelets. Type II affects $0.1 \%$ to $3 \%$ of patients on heparin, is caused by an immunologic mechanism, and is often associated with severe venous or arterial thrombosis. ${ }^{23} \mathrm{IgG}$ binds to the antigenic complex formed by heparin and $\mathrm{H} / \mathrm{PF} 4$, and, in turn, activates the platelets through their $\mathrm{Fc}$ receptors. ${ }^{1-4}$ Thrombocytopenia occurs within 5 to 15 days of heparin therapy and can occur earlier if sensitization with heparin already exists (Table 1). The antibodies could also react with endothelial cells and possibly provoke an immunologic vascular injury that could predispose the patient to thrombosis. 1,23

Some tests have been described to confirm the diagnosis of HIT. ${ }^{6}$ The platelet aggregation test is highly specific but poorly sensitive with a high incidence of false-positive tests. ${ }^{24}{ }^{*} 14 \mathrm{C}$-Serotonin release assays are both sensitive and specific but difficult to perform. ${ }^{25}$ Only an enzyme-linked immunosorbent assay (ELISA) test with heparin and PF4 reacting with IgG from the serum of susceptible patients could confirm the diagnosis, but ELISA is not performed by all laboratories. ${ }^{4}$

This patient appears to have first presented a type-I HIT with a transient decrease of her platelet count from 278,000 to $177,000 / \mathrm{mm}^{3}$ (Fig 1). Then, after a 3-day interruption of treatment, the reintroduction of heparin immediately provoked a catastrophic decrease of her platelet level to $34,000 / \mathrm{mm}^{3}$, evocative of a type-II HIT. She thereafter presented with postoperative thrombosis of her inferior vena cava and iliac and femoral veins. The transient cerebral ischemic attack that she sustained may not have been a thrombotic complication of HIT. At that time, she had not yet resumed recelving heparin, and thrombocytopenia was not present. Owing to its emergent nature, this case raises some important concerns.

Table 1. Characteristics of Type I and Type II HIT

\begin{tabular}{ll}
\hline \multicolumn{1}{c}{ Type I } & \multicolumn{1}{c}{ Type II } \\
\hline Frequent & Rare \\
Mild $(>100,000$ platelets $)$ & Severe $(<35,000$ platelets $)$ \\
Early $(<5$ days $)$ & $5-15$ days \\
Without thrombosıs & Associated with thrombosıs \\
Reversıble durıng heparın & Reversıble with heparın discon- \\
$\quad$ admınıstration & tınuatıon \\
Pro-aggregant effect of heparin & Immunologic reaction, IgG \\
$\quad$ on platelets & bındıng to $\mathrm{H} / \mathrm{PF} 4$ complex \\
\hline
\end{tabular}

Abbreviations lgG, ımmunoglobulın G; H/PF4, heparın/platelet factor 4
1. Heparin should have been stopped as soon as the diagnosis was suspected. ${ }^{6}$ The cardiologists refused to make this decision because of the expected risk of right coronary artery thrombosis at the level of the intraluminal stents. The heparin infusion was stopped in the operatıng room, and no heparin was added to the arterial flush. A single bolus dose of $50 \mathrm{IU} / \mathrm{kg}$ administered before the CPB was the only heparin source.

2. Plasmapheresis could have been performed preoperatively. This therapy could reduce or remove the offending antibodies from circulation ${ }^{13}$ but requires daily apheresis for at least 2 to 3 days preoperatively to obtain normalızation of the platelet count.

3. The heparin-coated CPB curcult should not have been used. Thrombocytopen1a has been described, associated with the use of heparin-coated catheters. ${ }^{26,27}$ Such catheters are coated with a heparın-benzalkonium chloride complex. ${ }^{5}$ Elution of heparin from these catheters has been demonstrated. ${ }^{27}$ Even this slow release of heparın could be sufficient to cause thrombocytopenia in patients with antiH/PF4 antibodies. ${ }^{27}$ This patient had a triple-lumen catheter in place (Arrow [Reading, PA]) that was not heparincoated. No pulmonary artery catheter was inserted.

HC-CPBs have some advantages over conventional uncoated circuits, all of them accounting for an increased biocompatibility. The artificial surfaces are less thrombogenic; the inflammatory response to CPB is reduced; and the platelets undergo less activation and functional deterıration. ${ }^{20-22}$ Two main types of HC-CPB circuits are manufactured: Duraflo II (Bentley) and Carmeda CBAS (Medtronic). In the first type of circurt, the tubing is coated with unfractionated porcine heparin, whereas in the second, it is coated with a fractionated heparin. The mode of binding of heparin in these circuits is different from the heparınbenzalkonium complex used on the pulmonary artery catheters and is also different in each of the two circuits. An lonic bindıng is used in the Duraflo II, and a covalent end-point attachment is used in the CBAS. The latter appears to account for a more stable heparin attachment ${ }^{5}$ with less release and more avalable actıve binding sites for antithrombin III The CBAS circuit could therefore be the better choice and has been successfully used, along with LMWH, in one case of HIT. ${ }^{28}$ Because of the emergency nature of the case and the availability of the circuits, the authors' choice was limited to a conventional circuit with full-dose $(300 \mathrm{IU} / \mathrm{kg})$ hepann or a Duraffo II circuit. They relied on a Duraflo circuit, and used low-dose porcine heparin $(50 \mathrm{IU} / \mathrm{kg})$. von Segesser ${ }^{29}$ showed that when HC-CPB is conducted without systemic heparinization, clottıng could occur in the zones of stagnation of blood and during the phases of low pump flow. Because this patient received 3,000 IU of heparin $(50 \mathrm{IU} / \mathrm{kg})$ and some heparin could have been released from the tubings during the bypass, this small amount may have been sufficient to aggravate the immunologic reaction, and hence the thrombocytopenia and the development of the postoperative deep venous thrombosis.

4. A heparin substitute should have been used. Some molecules are under clinical trial: dermatan sulfate, Orga- 
ran (Nourypharma, The Netherlands), ancrod, and hırudın (Table 2). Recombinant-hırudın is a potent thrombin inhibitor and has been used as the anticoagulant for cardiac operations ${ }^{16,30}$ and as a treatment for deep venous thrombosis. ${ }^{31}$ It has a short half-life in patients with normal renal function, and its effect could be monitored by means of activated partial thromboplastin time (aPTT) and ACT. However, r-hirudin has been found less effective than heparin in suppressing thrombin formation and fibrinopeptıde-A production. ${ }^{32}$ No antagonist is available.

Ancrod is a defibrinogenating enzyme purified from viper's venom. It selectively cleaves fibrinopeptide $\mathrm{A}$ and has been used as an alternate method of anticoagulation during CPB in HIT patients. ${ }^{14,15}$ Its infusion should be begun 12 hours preoperatively, and fibrinogen levels should be measured repetitively. Cryoprecipitates can be administered at the end of the surgery to reverse the effects of ancrod.

Heparinoids like dermatan ${ }^{33}$ and Orgaran (danaparoid sodium $)^{17}$ could be promising in such cases. Both of them have been used during CPB instead of heparin. Orgaran is said to have good antithrombotic activity with only minimal bleeding-enhancing activity and no effect on platelet function.

5. Use of LMWH during CPB has been proposed ${ }^{18,19}$ and also used as an alternative to unfractionated heparin for urgent surgery. ${ }^{34-38}$ However, even if patients receiving LMWH appear to have a lower incidence of thrombocytopenia, thrombosis, and antibody formation than those recerving standard heparin, ${ }^{39}$ some cases of HIT have been described with the use of LMWH, possibly caused by some cross-reactivity with the heparin-dependent antibodies. ${ }^{5,6}$ Moreover, biologic tests are insufficient to guide the therapeutıcs, and protamine has only a slight antagonistic effect. The authors relied on nadroparin (Fraxiparin [SanofiWinthrop, Bondeville, France] 0.6 mL BID) for the treatment of the postoperative thrombosis in the present patient. This, along with concomitant wafarin therapy and heparin discontinuation, allowed restoration of the platelet count to normal values in 3 days (Fig 1). In retrospect, it would have been judicious to test the absence of crossreactivity by aggregation tests before its administration.

6 . The platelets should have been protected with iloprost, aspurn, or dipyridamole ${ }^{7}$ before conventıonal $\mathrm{CPB}$ under a full dose of unfractionated heparin. This patient had not received aspirin for the last 10 preoperative days, and therefore a protective effect could not be expected. Successful use of the prostacyclin analog iloprost has often been described, ${ }^{10,11}$ but this drug was not available. Prostaglandin $\mathrm{I}_{2}\left(\mathrm{PGI}_{2}\right)$ does not seem to be as effective as iloprost in contrast to prostaglandin $\mathrm{E}_{2}$ that has been used as a substitute. ${ }^{12}$ However, these three drugs cause profound hypotension necessitating the concomitant infusion of vasopressors.

7. Platelets should not have been administered after protamıne admınıstration: They could have acted like "oil on the fire" and have been responsible for the observed postoperative thrombosis. However, their administration was deemed necessary because of continuing bleeding after protamine administration despite normalization of the ACT. Moreover, they were administered only after complete heparin reversal with protamine; therefore, no more heparin was circulating to form an immune complex able to react with the patient's IgG. Recently, Boshkov et al found a strong association between venous thrombosis and recent surgery of any type..$^{23}$ They considered HIT syndrome as a procoagulant disorder able to provoke thrombosis at sites of preexisting vascular pathology. The observed venous thrombosis can be either the consequence of the surgery or a complication of a low output state with venous stasis, as well as the consequence of the platelet infusion itself.

8. Immunoglobulins should have been administered postoperatively. Their administration has been described in HIT, along with platelet transfyision, based on their efficacy in restoring platelet count in immune thrombocytopenic purpura. ${ }^{40}$ In these two syndromes, immunoglobulin possibly works by blockıng the Fc receptor.

\section{COMMENTARY*}

The case presented illustrates many of the typical management problems associated with patients diagnosed with HIT who are undergoing surgery requiring heparinization.

First, the question of how the diagnosis of HIT was made and in fact whether the patient has HIT should be ascertained. The diagnosis of HIT may be obscured by the presence of other medical conditions or medications that may cause thrombocytopenia. Often, as presented in this case, laboratory tests such as ${ }^{14} \mathrm{C}$-serotonin release assay and heparin/PF4-IgG ELISA are simply not available, and clinical presentation is the sole basis for diagnosis. Either a decrease in platelet count of $30 \%$ of preheparin level or an unexpected thromboembolic event in a patient receiving heparın warrants consideration of the diagnosis of HIT.

*Mark E Comunale, MD

Table 2. Comparison of Heparin Substitutes for Use as Anticoagulants During CPB

\begin{tabular}{|c|c|c|c|c|}
\hline & LMWH & Hirudın & Ancrod & Dermatan \\
\hline Avallability & $(+)$ & $(-)$ & $(-)$ & $(-)$ \\
\hline Onset & Immediate & Immedıate & $12 \mathrm{~h}$ & Immediate \\
\hline Tests of efficacy & Anti Xa actıvity & TT, PT, APTT & $\begin{array}{l}\text { Plasma fibrinogen concentration } \\
\text { ACT ?-APTT }\end{array}$ & AntI-Ila activity, antr-Xa actıvity \\
\hline Antıdote & (Protamıne) & $(-)$ & Cryoprecipitate & $(-)$ \\
\hline Duration of action & $24 \mathrm{~h}$ & $30 \mathrm{~m} ı \mathrm{n}$ & & $40 \mathrm{~min}$ \\
\hline
\end{tabular}

Abbreviatıons: LMWH, low-molecular-weight heparın; ACT, activated coagulation time; APPT, actıvated partıal thromboplastın tıme; PT, prothrombın tıme, TT, thrombın tıme 
Sheridan et $\mathrm{al}^{25}$ have classified the likelihood of HIT based on the clinical setting. If thrombocytopenia develops in a patient receiving heparin and other causes are excluded, if thrombocytopenia recurs on challenge with heparin, or if acute arterial thrombosis occurs in the absence of other thrombotic factors, a diagnosis of "definite" HIT is made. The likelihood is designated "probable" if thrombocytopenia occurs in a patient receiving heparin and other causes are excluded; "possible" if these two criteria are present but the thrombocytopenia either resolves with continued heparin administration or fails to recur with a heparin challenge; or "unlikely" if another cause of thrombocytopenia is found or it fails to resolve on discontinuing the heparin.

Criteria that may also be present when the diagnosis of HIT is made are shown in Table 3 . However, these criterı are not necessarily all met before the diagnosis is made. An abrupt decline in platelet concentration on reexposure to heparin as occurred in this case strongly supports the diagnosis of HIT. However, it should be noted that HIT can occur in the absence of a decrease in platelet count, ${ }^{41}$ and occasionally, an unexpected thromboembolic event in a patient receiving heparın may be the first sign of HIT. In light of this, it is tempting to speculate that the cause of the patient's ischemia may have been heparin-induced platelet aggregation in the right coronary artery distribution.

Once the diagnosis has been established, choosing an appropriate management plan can be a challenge. As in many immune-mediated diseases, the presence of even trace amounts of antigen or antigen/hapten may be capable of inducing immunoglobulin-mediated reactions. Therefore, all hepảrin administration should be discontinued including the use of subcutaneous heparin. Saline should be substituted for heparin in pressure monitoring tubing and intravenous flush solutions, and heparin-bonded catheters should be removed.

If surgery requiring the use of heparin is not urgent, it should be postponed. Discontinuing heparin will result in a decrease in heparın-dependent antiplatelet antibodies over several weeks. Unfortunately, it is not possible to reliably predict how long antiplatelet antibodies will remain in the circulation. Patients rechallenged with heparin up to 2 months after recovery have become thrombocytopenic. ${ }^{42}$ Interestingly, although plasma heparin-dependent IgG d1minishes rapidly over 2 months after cessation of heparin exposure, platelets of sensitized patients are still capable of activation and aggregation, suggestıng a major portion of the heparin-dependent antibody may be membrane bound..$^{42}$

Table 3. Criteria That Are Usually Present When a Diagnosis of HIT Is Made

1 The patıent was not thrombocytopenıc before heparın admınıstration

2 A platelet count of less than $150,000 / \mu \mathrm{L}$ is determıned on two separate occasıons 24 hours apart durıng heparın therapy

3 Other causes of thrombocytopenia are excluded

4 A thrombotic event (venous or arterial) distinct from that for which the heparın was admınıstered occurs 2 or more days after inıtıation of heparin admınıstration.
In vitro tests of heparın-induced platelet aggregation and activation should follow and will gradually become negative. ${ }^{43}$ Several patients in whom surgery was delayed until platelet aggregation studies were negative underwent uneventful heparinization and CPB. ${ }^{43}$

When surgery cannot be postponed as in this case, the choice of management is between the use of heparin with concomitant administration of agents that prevent heparıninduced platelet activation (for example iloprost, a $\mathrm{PGI}_{2}$ analog, or $\mathrm{PGE}_{1}$ ), LMWH preparations, ancrod, or other nonheparm anticoagulation agents

The authors' use of a heparin-bonded CPB circuit is a novel approach, and they are to be congratulated on their creativity in a desperate circumstance. However, it also raises important concerns. Although the use of heparinbonded CPB circuits has been shown to produce better platelet preservation, ${ }^{44}$ the presence of a heparin-dependent IgG in patients with HIT complicates the scenario. The Duraflo II CPB circuit is manufactured by a process called "unıversal bonding" whereby unfractionated heparın molecules are modified and attached to the circuit using a proprietary formulation. ${ }^{45}$ Although the stability of the heparin bonding on the Duraffo II circult is superior to other heparin-bonded circuits, leaching of bound heparin from the circuit into the circulation still occurs ${ }^{45}$ and could precipitate platelet activation and aggregation in patients with HIT. It is also likely that heparin that is bound on the crrcuit can interact with PF4 to form the reactive antigen on the platelet surface. The presence of a heparın-dependent IgG in patients with HIT would allow binding of this complex with subsequent activation of platelets. Perhaps even more important, systemic heparin administration is still required when using a heparin-bonded $\mathrm{CPB}$ circuit. Fifty IU heparin $/ \mathrm{kg}$ is very likely to precipitate HIT in susceptible patients with specific IgG.

The early postoperative bleeding and extensive thrombosis that occurred in the patient presented is not an unexpected outcome in patients with HIT who are exposed to heparin without the concomitant use of agents that prevent platelet activation. This unfortunate outcome might have been prevented by the concomitant use of prostaglandin $E_{1}$ from immediately after induction of anesthesia through heparin neutralization and chest closure. $\mathrm{PGE}_{1}$, like $\mathrm{PGI}_{2}$, inhibits platelet activation and aggregation by increasing intracellular concentrations of platelet cyclic adenosine monophosphate. ${ }^{46}$ Hypotension associated with the use of prostaglandins can be prevented by simultaneous infusion of vasopressors such as phenylephrine.

Alternatively, the use of other management pathways such as ancrod, LMWHs, antiplatelet agents, or hirudin can be considered. Unfortunately, some of these agents may be unavailable (hirudin), are of limited efficacy (LMWH, antiplatelet agents), or are associated with severe adverse side effects (ancrod). The small number of patients presenting with HIT has also contributed to the lack of controlled trials in this area. In fact, iloprost, one of the most promising agents for managing patients with HIT, was 
denied approval by the Food and Drug Administration citing lack of control trials (personal communication, Berlex Laboratories, Wayne, NJ).

Argatroban, a small molecular direct thrombin inhibitor that rapidly, selectively, and reversibly binds the catalytic site of thrombin, is currently undergoing clinical trials and may be avallable soon for the management of patients with HIT. ${ }^{47}$

\section{REFERENCES}

1. Aster RH' Heparin-induced thrombocytopenia and thrombos1s N Engl J Med 332·1374-1376, 1995 (editorial)

2. Kelton JG, Smith JW, Warkentın TE, et al Immunoglobulın $\mathrm{G}$ from pattents with heparin-induced thrombocytopenia binds to a complex of heparm and platelet factor 4 Blood 83 3232-3239, 1994

3 Gremacher A, Potzsch B, Amiral J, et al Heparin-associated thrombocytopenia. Isolation of the antıbody and characterization of a multımolecular PF4-heparin complex as the major antigen Thromb Haemost 71-247-251, 1994

4 Amural J, Bridey F, Wolf M. et al. Antibodies to macromolecular platelet factor 4-heparin complexes in heparin-induced thrombocytopen1a. A study of 44 cases. Thromb Haemost 73.21-28, 1995

5. Gravlee GP: Anticoagulation for cardiopulmonary bypass, in Gravlee GP, Davis RF, Utley JR (eds) C Cardıopulmonary Bypass. Principles, and Practıce Baltimore, W1llıams \& W1lkıns, 1993, pp 364-369

6 Singer RL, Mannion JD, Bauer TL, et al Complications from heparin-induced thrombocytopenia in patients undergoing cardiopulmonary bypass. Chest $104 \cdot 1436-1440,1993$

7. Palmer Smith J, Walls JT, Muscato MS, et al: Extracorporeal circulation in a patient with heparın-ınduced thrombocytopenıa Anesthesiology 62-363-365, 1985

8. Munver R. Schulman IC, Wolf DJ, et al: Heparın-induced thrombocytopenia and thrombosis' presentation after cardiopulmonary bypass Ann Thorac Surg 58:1764-1766, 1994

9 Kalangos A. Relland JY, Massonet-Castel S, et al Heparininduced thrombocytopenia and thrombosis following open heart surgery. Eur J Cardıothorac Surg 8•199-203, 1994

10 Kraenzler EJ, Starr NJ: Heparin-associated thrombocytopenua Management of patients for open heart surgery Case reports describing the use of iloprost. Anesthesiology 69 964-967, 1988

11 Corbeau JJ, Jacob JP, Moreau X, et al' Iloprost (Ilomedine) et circulation extracorporelle avec héparınısatıon conventıonnelle chez un patıent ayant une thrombocytopénıe à l'héparıne. Ann Fr Anesth Réanım 12.55-59, 1993

12 Shorten G, Comunale ME, Johnson RG: Management of cardiopulmonary bypass in a patient with heparin-induced thrombocytopenia using prostaglandin E1 and aspirin J Cardiothorac Vasc Anesth 8·556-558, 1994

13. Brady J, Riccio JA, Yumen OH, et al- Plasmapheresis A therapeutic option in the management of heparin-associated thrombocytopen1a with thrombosıs. Am J Clin Pathol 96:394-397, 1991

14. O Yurvat1 AH, Laub GW, Southgate TJ. et al. Heparmless cardiopulmonary bypass with ancrod Ann Thorac Surg 57.16561658,1994

15. Spiekermann BF, Lake CL, Rich GF, et al Normal activated clotting time despite adequate anticoagulation with ancrod in a patient with heparin-associated thrombocytopenia and thrombosis undergoing cardiopulmonary bypass Anesthesiology 80:686-688, 1994

16. Riess FC, Lower C, Seelig C, et al: Recombınant hirudin as a new antıcoagulant durıng cardiac operatıons instead of heparın. Successful for aortic valve replacement in man. J Thorac Cardiovasc Surg 110 265-267, 1995

17. Chong BH, Mangnanı HN: Orgaran in heparın-ınduced thrombocytopenia. Haemostasis 22:85-91, 1992

18. Robitalle D, Leclerc JR, Laberge R, et al. Cardıopulmonary bypass with a low-molecular-weight heparm fraction (enoxaparin) in a patient with a history of heparin-associated thrombocytopenı. J Thorac Cardiovasc Surg 103.597-599, 1992

19 Altés A, Martıno R, Garı M. et al Heparın-ınduced thrombocytopenıa and heart operation Management with tedelparın. Ann Thorac Surg 59:509-511, 1995

20 Videm V, Mollnes TE, Garred P, et al Biocompatibility of extracorporeal circulatıon. In vitro comparison of heparın-coated and uncoated oxygenator cırcuits. $J$ Thorac Cardıovasc Surg $101 \cdot 654-660,1991$

21. Fosse E, Moen O, Johnson E, et al Reduced complement and granulocyte activation with heparın-coated cardiopulmonary bypass Ann Thorac Surg 58:472-477, 1994

22 Svennevig JL, Geiran OR, Karlsen H, et al: Complement activation during extracorporeal circulation. In vitro comparison of Duraflo II heparin-coated and uncoated oxygenator circults J Thorac Cardıovasc Surg 106:466-472, 1993

23 Boshkov LK, Warkentın TE, Hayward CP, et al Heparıninduced thrombocytopenia and thrombosis: Clinical and laboratory studies. Br J Haematol 84·322-328, 1993

24 Kelton JG, Sherıdan D, Brain $\mathrm{H}$, et al Clınical usefulness of testıng for a heparin-dependent platelet-aggregating factor in patıents with suspected heparın-associated thrombocytopenı J Lab Clin Med 103 606-612, 1984

25 Sheridan D, Carter C, Kelton JG. A diagnostic test for heparın-induced thrombocytopenia. Blood 67 27-30, 1986

26 Moberg PQ, Geary VM, Sheikh FM- Heparın-induced thrombocytopenia A possible complication of heparin-coated pulmonary artery catheters. J Cardıothorac Anesth 4:226-228, 1990

27 Laster J, Silver D Heparin-coated catheters and heparıninduced thrombocytopenta I Vasc Surg 7:667-672, 1988

28 Couyant MA, Beemer GH, Tatoulis J, et al: A proposed protocol for the management of cardiopulmonary bypass for patients with heparın-induced thrombocytopenia syndrome Austras Perfusion Soc J 1 33-36, 1992

29. von Segesser LK, Weiss BM, Pasıc M, et al· Rısk and benefit of low systemic heparınization during open heart operations. Ann Thorac Surg 58·391-398, 1994

30. Walenga JM, Bakhos M, Messmore HL, et al: Potential use of recombinant Hirudin as anticoagulation in a cardiopulmonary bypass model Ann Thorac Surg 51:271-277, 1991

31 Nand S: Hirudin therapy for heparın-associated thrombocytopenia and deep venous thrombosis. Am J Hematol 43:310-311, 1993

32 Edmunds LH Jr" HIT, HITT, and desulfatohırudın. Look before you leap J Thorac Cardiovasc Surg 110:1-3, 1995 (editorial)

33. Brister SJ, Buchanan MR Heparınless cardiopulmonary bypass revisited A newer strategy to avoid heparin-related bleeding using dermatan sulfate J Cardiothorac Vasc Anesth 9·317-321, 1995

34. Gouault-Hellmann M, Huet Y. Contant G, et al: Cardiopulmonary bypass with a low-molecular-werght heparin fraction Lancet II 1374, 1983 (letter)

35. Massonnet-Castel S, Pelissier E, Dreyfus G, et al: Lowmolecular-weight heparin in extracorporeal circulation. Lancet I 1182-1183, 1984 (letter)

36 Roussi JH, Houbouyan LL, Goguel AF. Use of lowmolecular-weight heparın in heparın-Induced thrombocytopenia with thrombotic complications Lancet I.1183, 1984 (letter) 
37 Dreyfus G, Massonnet-Castel S, Pélissier E, et al. Etude d'une héparıne de bas poids moléculaire au cours des circulatıons extracorporelles. Premıères applicatıons clınıques Arch Mal Coeur 13.1851-1857, 1986

38. Drakos P, Uziely B, Nagler A, et al: Successful admınıstration of low molecular weight heparin in a patient with heparın induced thrombocytopenia and coumarin-induced skin necrosis Haemostasis 23.259-262, 1993

39 Warkentın TE, Levine MN, Hirsh J, et al Heparın-induced thrombocytopenia in patients treated with low-molecular-weight heparın or unfractionated heparın. N Engl J Med 332·1330-1335, 1995

40. Frame JN, Mulvey KP, Phares JC, et al: Correction of severe heparın-associated thrombocytopenia with intravenous immunoglobulın Ann Intern Med 111 946-947, 1989

41. Kappa JR, Fisher CA. Berkowitz HD, et al Heparıninduced platelet activation in sixteen surgical patients: Diagnosis and management. J Vasc Surg 5 101-109, 1987
42. Kapsch DN, Adelstem EH, Rhodes GR, et al: Heparıninduced thrombocytopenia thrombosis, and hemorrhage. Surgery 86:148-155, 1979

43. Olinger GN, Hussey CV, Olive JA: Cardıopulmonary bypass for patients with previously documented heparin-Induced platelet aggregation. J Thorac Cardıovasc Surg 87-673-677, 1984

44 Thelın S, Bagge L, Hultman J, et al- Heparın-coated cardiopulmonary bypass circuits reduce blood cell trauma. Exper1ments in the pıg Eur J Cardiothorac Surg 5:486-491, 1991

45 Hsu L-C Heparın coating of bypass circuits. Principles of heparin-coatıng techniques Perfusion 6.209-219, 1991

46 Gorman RR, Buntıng S, Miller OV Modulation of human platelet adenylate cyclase by prostacyclın (PGX) Prostaglandins 13:377-388, 1977

47. Schwarz RP, Becker JC, Brooks RL, et al The preclmical and clinical pharmacology of NOVASTAN (Argatroban) A smallmolecule, dırect thrombin inhibitor J Clin Appl Thromb Hemo (accepted for publication) 